\title{
PENDAMPINGAN TERHADAP GURU SEKOLAH MENENGAH PERTAMA MENGIDENTIFIKASI MASALAH BELAJAR SISWA PADA MATA PELAJARAN BAHASA INDONESIA
}

\author{
Oleh \\ Sri Sugiarto ${ }^{1)}$, Riadi Suhendra ${ }^{2)}$ \\ ${ }^{1), 2)}$ Pendidikan Bahasa \& Sastra Indonesia Fakultas Keguruan dan Ilmu Pendidikan \\ Universitas Samawa \\ Sri.sugiarto90@gmail.com
}

\begin{abstract}
ABSTRAK
Memperbaiki kualitas hasil belajar siswa merupakan salah satu hal penting yang semestinya dikerjakan oleh guru. Untuk dapat melakukan hal tersebut, guru seharus memiliki kemampuan dan kemauan melakukan identifikasi masalah belajar siswa. Namun, kenyataanya tidak semua guru memiliki kemampuan dan kemauan tersebut. Oleh karena itu, bentuk pengabdian masyarakat berupa pendampingan mengidentifikasi masalah belajar siswa salah satu program yang sangat dibutuhkan oleh guru terutama di SMP Negeri 4 Badas khususnya guru Bahasa Indonesia. Kegiatan ini dilakasanakan pada awal bulan Juli sampai akhir Agustus 2017 Bentuk pendampingan identifikasi kesuliatan yang diterapkan dalam pendampingan dengan tiga hal utama, yaitu identifikasi berdasarkan hasil kerja siswa, identifikasi berdasarkan observasi kelas, dan identifikasi berdasarkan aspirasi siswa. Berdasarkan hasil kegiatan pendampingan, dapat digambarkan kegiatan program ini dapat dikatakan berhasil. Hal ini berdasarkan hasil evaluasi kemampuan guru mencapai $85 \%$ terhadap materi dan kemapuan mengidentitifikasi kesuliatan belajar siswa. Selain itu, Adanya respon yang positif dari peserta mengingat kegiatan pengabdian ini merupakan kebutuhan guru dalam rangka peningkatan profesionalitasnya dan meningkat kualitas belajar siswa.
\end{abstract}

Kata Kunci: identifikasi, masalah, belajar

\section{PENDAHULUAN}

Pendidikan merupakan hak bagi setiap manusia. Pendidikan menghasilkan kecerdasan, dan kecerdasan sangat mempengaruhi kehidupan di era modern ini. Pendidikan wajib ditempuh bagi semua orang, terlebih di Indonesia yaitu semua warga negara berhak mendapatkan pendidikan selama 9 tahun. Hal ini sejalan dengan UU. No. 20 tahun 2003, Pendidikan adalah usaha sadar dan terencana untuk mewujudkan suasana belajar dan proses pembelajaran agar peserta didik secara aktif mengembangkan potensi diri secara aktif mengembangkan potensi dirinya untuk memiliki kekuatan spiritual keagamaan, pengendalian diri, kepribadian, kecerdasan, akhlak mulia, serta keterampilan yang diperlukan dirinya, masyarakat, bangsa, dan Negara.

Jadi, dapat ditarik kesimpulan, bahwasanya pendidikan adalah usaha sadar dan terencana dalam proses pengubahan sikap dan tata laku seseorang untuk 
mengembangkan kepribadian sesuai nilai-nilai dalam masyarakat dan kebudayaan melalui pengajaran dan pelatihan. Dalam proses pengubahan baik sikap maupun tingkah laku seseorang tidak terlepas dari pengajaran dan pelatihan, dalam hal ini belajar sangat penting demi menunjangnya suatu pendidikan yang baik dan berhasil.

Belajar adalah kegiatan yang berproses dan merupakan unsur yang sangat fundamental dalam penyelenggaraan setiap jenis dan jenjang pendidikan. Ini berarti bahwa berhasil atau gagalnya pencapaian tujuan pendidikan itu amat bergantung pada proses belajar yang dialami siswa, baik ketika berada di sekolah maupun di lingkungan rumah atau keluarganya sendiri. Oleh karena itu, pemahaman yang benar mengenai arti belajar dengan segala aspek, bentuk, dan manifestasinya mutlak diperlukan oleh para pendidik khususnya para guru. Kekeliruan atau ketidaklengkapan persepsi mereka terhadap proses belajar dan hal-hal yang berkaitan dengannya mungkin akan mengakibatkan kurang bermutunnya hasil pembelajaran yang dicapai peserta didik.

Adapun pemaparan dari beberapa perspektif para ahli tentang pengertian belajar. Dalam The Guidance of Learning Activities W.H. Burton (1984) mengemukakan bahwa "Belajar adalah proses perubahan tingkah laku pada diri individu karena adanya interaksi antara individu dengan individu dan individu dengan lingkungannya, sehingga mereka lebih mampu berinteraksi dengan lingkungannya". Sementara Ernest R. Hilgard (1992:25) dalam introduction to Psychology mendefinisikan "Belajar sebagai suatu proses perubahan kegiatan, reaksi terhadap lingkungan".

Dari berbagai perspektif pengertian belajar sebagaimana dijelaskan di atas, maka dapat disimpulkan bahwa belajar adalah suatu proses perubahan tingkah laku pada diri individu dalam interaksi dengan lingkungannya secara aktif dan integratif untuk mencapai suatu tujuan. Adapun dalam setiap pembelajaran pasti muncul suatu permasalahn, dimana permasalahan itu adalah ketika siswa mengalami kesulitan dalam menerima pelajaran, berbagai faktor yang membuat kesulitan belajar siswa.

Kesulitan belajar adalah Secara harfiah kesulitan belajar merupakan terjemahan dari Bahasa Inggris "learning Disability yang berarti ketidakmampuan belajar. Kata disability diterjemahkan kesulitan" untuk memberikan kesan optimis bahwa anak sebenarnya masih mampu untuk belajar.

Adapun permasalahan belajar itu ada dua. Pertama, masalah belajar internal adalah masalah yang ditimbulkan dari dalam diri siswa atau adanya faktor-faktor internal yang 
menimbulkan kesulitan siswa dalam belajar. Kedua, masalah belajar eksternal adalah masalah yang ditimbulkan dari luar diri siswa, atau adanya faktor-faktor eksternal yang menimbulkan kesulitan siswa dalam belajar.

Kesulitan tersebut dalam hal menyimak, berbicara, membaca, menulis, dan berhitung. Kondisi ini bukan karena kecacatan fisik atau mental, bukan juga karena pengaruh faktor lingkungan, melainkan karena faktor kesulitan dari dalam individu itu sendiri saat mempersepsi dan melakukan pemrosesan informasi terhadap objek yang diinderainya. Kesulitan belajar adalah kondisi dimana anak dengan kemampuan intelegensi rata-rata atau di atas rata-rata, namun memiliki ketidakmampuan atau kegagalan dalam belajar yang berkaitan dengan hambatan dalam proses persepsi, konseptualisasi, berbahasa, memori, serta pemusatan perhatian, penguasaan diri, dan fungsi integrasi sensori motorik. Berdasarkan pandangan Clement, kesulitan belajar adalah kondisi yang merupakan sindrom multidimensional yang bermanifestasi sebagai kesulitan belajar spesifik (spesific learning disabilities), hiperaktivitas atau distraktibilitas dan masalah emosional. Kelompok anak dengan Learning Dissability (LD) dicirikan dengan adanya gangguan-gangguan tertentu yang menyertainya.

Pada dasarnya setiap siswa itu memiliki perbedaan masing-masing, baik dalam hal intektual, kebiasaan, latar belakang orang itu sendiri bahkan kemampuan fisik dia sendiri. Dengan sejumlah karakteristik siswa yang beraneka ragam. Ada siswa yang lancar dan berhasil dalam kegiatan belajarnya tanpa mengalami kesulitan, akan tetapi disisi lain pula banyak siswa yang mengalami kesulitan dalam belajarnya. Burton, (1984) mengidentifikasi bahwa seorang siswa dapat diduga mengalami kesuliatan belajar, jika siswa menunjukkan keggalan tertentu dalam mencapai tujuan pembelajaran tertentu. Sejalan ini, Slameto (2003: 54) menyebutkan dua factor utama yang menjadi penyebab siswa sulit belajar, yaitu (1) faktor internal yang berasal dari diri siswa yang meliputi kesehatan, keadaan fisik, intelegensi, dan minat. Sedangkan factor (2) faktor ekternal yang meliputi lingkungan siswa seperti lingkuangan keluarga, masyarakat, dan sekolah.

Kabupaten Sumbawa Besar memiliki tingkat sekolah pertama (SMP) sederajat sebanyak 36 sekolah. Mencermati masalah dari hasil wawancara beberapa guru SMP di Sumbawa, dapat disimpulkan bahwa mereka mengalami kesulitan untuk mengetahui dan mengidentifikasi masalah berlajar siswa. 
Dengan mencermati kondisi tersebut, guru bahasa Indonesia perlu mengakui bahwa perlu melakukan pendampingan mengidentifikasi masalah berlajar siswa. Kegiatan ini diharapakan oleh guru guna meningkatkan profesionalitas sebagai seorang guru. Kegiatan pendampingan guru ini akan dilakukan pada SMP Negeri 4 Labuhan Badas.

Berdasakan analisis situasi pada sekolah yang berada di Kota Sumbawa Besar, terutama pada sekolah mitra, maka dapat dirumuskan pemesalahan yang dihadapi oleh mitra. (1) Motivasi para guru untuk berinovasi dan mengembangkan pembelajaran yang tepat digunakan masih sangat rendah karena sebagian guru sekolah mitra jarang mengikuti pertemuan-pertemuan ilmiah yang berkaitan dengan masalah. (2) Kurangnya kesadaran dan pemahaman para guru tentang mehami dan memanfaatkan kesulitan belajar siswa dalam meningkatkan kualitas belajar belajar siswa.

\section{METODE PENDAMPINGAN}

Dua masalah yang telah diuraikan pada bagian permasalahan yang dihadapi oleh mitra perlu diwujudkan solusinya dengan beberapa tahapan. Tahapan-tahapan yang akan dilaksanakan untuk mencapai target yang diharapkan akan dilakukan dengan tahapan-tahapan berikut.

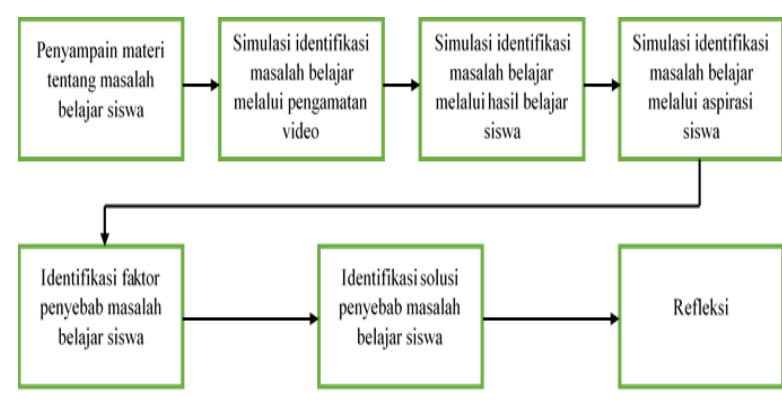

Bagan 1. Metode Pelaksanaan Kegiatan Pendampingan

Kegiatan pendampingan ini akan dilaksanakan tujuh tahapan. Tahapan pertama dimulai degan penyampain meteri motivasi pentingnya peningkatan professional guru dan masalah belajar siswa. Kemudian dilanjutkan dengan tahapan kedua dengan simulasi mengidentifikasi masalah belajar melalui pengamatan video. Tahap ketiga melakukan simulasi identifikasi masalah belajar melalui hasil belajar siswa. Tahapan keempat simulasi identifikasi masalah melalui aspirasi siswa. Tahapan kelima mengidentifikasi faktor penyebab masalah belajar siswa. Tahapan keenam mengidentifikasikan solusi faktor penyebab masalah belajar siswa. Tahapan ketujuh melakukan refleksi.

\section{HASIL DAN PEMBAHASAN}

\section{Hasil Pelaksanaan Kegiatan}

Pemaparan hasil

kegiatan

pendampingan ini diuraikan berdasarkan tahapan-tahapan kegiatan yang pelaksanaan. Hasil kegiatan pertama, penyampain materi tentang masalah belajar siswa dapat belajar tercapai dengan ketuntasan $85 \%$. 
Kegiatan selanjutnya, kegiatan simulasi identifikasi berdasarkan pengamatan video. Pada kegiatan ini, para guru sangat antusias mengidentifikasi faktafakta yang ada di video. Berdasarkan fakatafakta yang ditemukan ini, selanjutnya guru mengidentifikasi fakta-fakta yang merupakan masalah pembelajaran.

Kegiatan ketiga, yaitu simulasi identifikasi masalah berdasarkan hasil karya siswa. Pada kegiatan ini, guru mengerjakan lembar kerja untuk mengidentifikasi masalah berdasarkan hasil karya tersebut.

Kegiatan simulasi identifikasi masalah berdasarkan aspirasi, pada kegiatan ini guru mengamati video pembelajaran yang menunjukkan seorang guru memancing siswa untuk menyampaikan aspirasi siswa.

\section{PEMBAHASAN}

Kegiatan pendampingan identifikasi masalah belajar siswa bagi guru SMP 4 Labuan Badas sebagai upaya meningkatkan kualitas belajar siswa dilaksanakan pada tanggal 4 Juni- 26 Agustus 2017. Kegiatan pendampingan ini berlancar dengan lancar. Kegiatan pendampingan ini ditujukan pada guru mata pelajaran bahasa Indonesia kelas X dan kelas XI. Selama pendampingan, guruguru terlihat antusias dan merasa terbantu mengidentifikasi masalah belajar siswa.

Setelah mengikuti kegitan ini, para guru telah mampu memahami tentang masalah belajar siswa. Hal ini dintunjukkan dengan tingkat ketercapai $85 \%$. Beberapa masalah yang dapat ditemukan berdasarkan hasil observasi pembelajaran antaranya: (1) Sebagian besar siswa terlihat bosan serta tidak fokus mengikuti pembelajaran; (2) Siswa tidak serius dalam belajar kelompok; (3) Tidak ada keterkaitan antara pembelajaran hari pada hari itu dengan pembelajaran sebelumnya; (4) Suasana kelas terdengar sangat rebut; (5) siswa tidan mampu mengungkapkan ide; (6) siswa tidak mampu mebedakan isi dua bacaan; dan (7) kurang kreativitas guru membuat media pembelajar. Selain itu, masalah yang dapat ditemukan dari hasil belajar siswa diantaranya: (1) siswa masih banyak melakukan kesalahan menggunakan tanda baca dan huruf; (2) siswa belum mampu menyusun kalimat yang efektif; (3) siswa belum mampu merangkai kalimat yang runtut dalam paragraf. Selanjutnya, berdasarkan hasil aspirasi siswa, ditemukan bahwa rata-rata siswa berkeinginan kegiatan pembelajaran dilakukan di luar kelas.

$$
\text { Selanjutnya, kegiatan }
$$

mengidentifikasi faktor penyebab masalah belajar siswa sudah mencapai tingkat ketercapain $80 \%$. Berdasarkan hasil identifikasi masalah belajar ditemukan pada kegiatan sebelumnya, para guru dapat mengidentifikasi factor penyebabnya sebagai berikut. (1) Guru tidak kreatif dan tidak 
menyiapkan alat peraga yang menarik minat siswa; (2) Guru tidak memberikan tugas yang jelas pada masising siswa dalam kelompok; (3) Guru tidak memberikan bimbingan pada saat proses diskusi kelompok; (4) Guru kurang menguasai kelas; (5) Guru melakukan pembiaran; dan (6) Metode yang digunakan tidak tepat; (7) Kurang pembedaharaan kata bahasa Indonesia sehingga tidak mengetahui arti yang penekanan perintah tugas; (8) Siswa tidak tahu kaidah penggunan huruf; (9) Guru tidak menjelaskan kaidah penggunaan huruf; (10) Guru melakukan pembiaran kesalahan penggunaan huruf.

\section{Faktor Pendukung Kegiatan}

Kegiatan pendampingan ini dapat berjalan dengan lancar. Hal ini disebabkan adanya faktor yang mendukung berjalannya kegitan pengabdian. Hal-hal yang mendukung berjalannya kegiatan pengabdian ini dapat diidentifikasi diantaranya antusisme para guru mata pelajaran dan kepala sekolah. Faktor yang mendukung kegiatan adalah antusiasme peserta untuk memahami knsep pengembangan karya profesi, arti penting karya pengembangan profesi, pentingnya peningkatan kualitas dan kuantitas karya profesi serta kemauan dari peserta pengabdian untuk menulis. Antusiasme diwujudkan dengan banyaknya pertanyaan yang muncul ketika pelaksanaan diskusi dan kegiatan pendampingan, dan dari hasil identifikasi masalah, faktor penyebab, dan solusi pemecahan masalah berlajar siswa.

\section{Faktor Penghambat}

Lancarnya pelaksanaan kegiatan pengabdian bukan berari tanpa hambatan. Selama pengabdian ada beberapa hal yang diidentifikasi sebagai faktor penghambat kegiatan pengabdian diantaranya adalah keterbatasan waktu pendampingan.

\section{SIMPULAN DAN SARAN}

\section{Simpulan}

Kegiatan pengabdian terhadap guru sekolah menengah pertama mengidentifikasi masalah belajar siswa guru sangat antusias dan merasakan manfaat pendampingan. Pelaksanaan pengabdian untuk guru-guru dapat disimpulkan berhasil. Keberhasilan ditunjukkan antara lain (1) Adanya respon yang positif dari peserta mengingat kegiatan pengabdian merupakan kebutuhan guru dalam rangka peningkatan profesionalitasnya dan meningkat kualitas belajar siswa. (2) Berdasarkan ketercapain indikator pencapaian para guru sudah mampu mengidentifikasi masalah, faktor penyebab, dan solusi pemecahan masalah berlajar siswa.

\section{SARAN}

Saran yang dapat diberikan pada guru yang berperan penting dalam meningkat kuaitas belajar siswa, yakni dengan pengalam pendamingan ini dapat ditingkatkan dan dilanjutkan pada kegitan pembelajaran 
bahasa berikutnya. Selain itu, diharapkan pengalaman yang telah didaperoleh mampu ditulari kepada guru-guru lainnya.

\section{DAFTAR PUSTAKA}

Arifin, Zainal. 2013. Evaluasi pembelajaran (prinsip, tekhnik, prosedur)Bandung: Remaja Rosdakarya.

Makmun, Abin Syamsuddin. 2009. Psikologi Kependidikan. Bandung: Remaja Rosdakarya.

Goodman, Keneth S. 1986. Literacy: for Whom and What. Language in Learning.Selected Papers from the RELC Seminar on Language Accross the Curriculum Singapore, 22-26 April 1985.

Suyono. 2007. Dimensi, Jenjang, dan Asesmen Perilaku Berliterasi Siswa di Sekolah. Jurnal Ilmu Pendidikan, Jilid 14, Nomor 2, Juni 2007, hal. 69-75.

DeStefano, Johanna S. 1984. Learning to Communicate in the Classroom. The Development of Oral and Written Language in Social Contexts.Pellegrini, Anthony D. dan Thomas D. Yawkey (eds.). Norwood: Ablex Publishing Co. DEETYA/Departement of Employment, Education, and Training and Youth Affairs Australia 